\title{
1 Gender, climate change and the politics of vulnerability
}

\author{
An introduction
}

\author{
Nitya Rao, Anjal Prakash, Asha Hans, and \\ Amrita Patel
}

\section{Introduction}

Climate change is transforming countries the world over, and the South Asian subcontinent is no exception. Floods, heatwaves, weak monsoons and unseasonal rains, all occurring in a relatively short timeframe, are adversely affecting millions of poor people (Ramanathan et al. 2005; Amarnath et al. 2017; Vinke et al. 2017; Gunaratna 2018, Pant et al. 2018). The nature of the risks confronting their lives and livelihoods are becoming increasingly unpredictable. Worst affected are the poor and marginalized living in 'climate hotspots', namely, coastal areas, mountain ranges, semi-arid regions and cities (De Souza et al. 2015; Ford et al. 2015; Sivakumar and Stefanski 2010). Those whose livelihoods are directly dependent on agriculture and the agrarian economy remain the most vulnerable (Farooqi et al. 2005; Gentle and Maraseni 2012). Climate-induced floods in many parts of Bangladesh, for instance, are threatening the food security of the poor (Faisal and Parveen 2004; Yu et al. 2010), while in the Indus river basin of Pakistan, the lack of information and resource access further constrains people's abilities to adapt to the changing climate (Rasul et al. 2012; Abid et al. 2015).

Even though research and policy are often framed in terms of climate change impacts alone, our starting point is the recognition that climate change aggravates pre-existing socio-economic vulnerabilities and everyday risks that the poor confront in their daily lives (Allen et al. 2018; IPCC 2019). Such 'contextual vulnerability' is based on a processual and multidimensional view of climate-society interactions (O'Brien et al. 2007). There is growing recognition in research on climate change that both perceptions of risk and its impacts on people are associated with social position and identity, in particular gender, and of the ways in which this intersects with other factors like class, caste/ethnicity and age (Dankelman et al. 2008; MacGregor 2010; Goodrich et al. 2019).

The impacts of climate change could prove particularly severe for some women, yet very little research that is both disaggregated and contextually embedded is available (Cannon 2002; Demetriades and Esplen 2008; Djoudi et al. 2016; Pearse 2017). This book is an attempt to fill this gap, focusing on the gendered experiences of climate change across different 


\section{Nitya Rao et al.}

geographies and social contexts in South Asia. Moving beyond the binaries of women and men, we conceptualize gender in terms of the unequal power relations between women and men across social groups (Rao and Kelleher 2005; Rao et al. 2019). We also include the implications of these intersecting (dis)advantages for both material conditions and social positions, which in turn shape strategies for coping with and adapting to climate change (Young 2016).

In this introduction, we set out the key issues present in the debates on climate change from a gender and South Asian perspective, emphasizing the need to take on board the specificities of locational and cultural vulnerabilities, experiences and opportunities, in order to sensitively address issues of adaptation. We understand vulnerability as "a state of susceptibility to harm from exposure to stresses associated with environmental and social change and from the absence of capacity to adapt" (Adger 2006: 268; Otto et al. 2017). Vulnerability is closely associated with the multiple risks - climatic, market, social - that people confront, but equally with the social, cultural, political and institutional contexts in which they are embedded (Rao et al. 2020). Adaptation, then, includes the "plans, actions, strategies or policies to reduce the likelihood and/or consequences of risks or to respond to such consequences" (IPCC 2018).

The chapters in this collection are based on research generated through the Collaborative Adaptation Research Initiative in Asia and Africa (CARIAA) funded by the Canadian International Development Research Centre and the UK Department for International Development. Over the past five years, CARIAA has sought to understand climate change impacts on vulnerable communities through four consortia working in three distinct agro-ecological regions: ASSAR (Adaptation at Scale in Semi-Arid Regions) and PRISE (Pathways to Resilience in Semi-Arid Economies) working in semi-arid regions; DECCMA (Deltas, Vulnerability and Climate Change: Migration and Adaptation) in delta regions; and HI-AWARE (Himalayan Adaptation, Water and Resilience) working on glacier- and snowpack-dependent river basins. The authors include both established and up-and-coming researchers, and the chapters reflect a mix of expertise and methodologies. Empirical evidence is drawn from quantitative, qualitative and participatory research.

\section{Gender and climate change: a view from South Asia}

The global literature focusing on gender and climate change, though still evolving (Denton 2002; Dankelman 2010; Arora-Jonsson 2011), establishes with high confidence that gender relations are an integral part of climate-change processes and the social transformations these set in motion (Pearse 2017). This is because the immediate effects of changing climate are felt in the natural resource-dependent sectors - agriculture, forestry and water - where women's involvement in farming, water collection and use, or biomass collection for cooking, is historically sizeable (Dixon-Mueller 2013). 
With the increasing unpredictability of rainfall and temperatures, men tend to migrate to urban and peri-urban areas as a pre-emptive risk-reduction strategy, leaving women behind in the rural areas to bear the near total burden of everyday survival in their absence (Rajasree 2010; Rao et al. 2019).

A view from South Asia does not appear very different on the surface, though this remains an under-researched area, given the deep fissures created by caste, marital status and class. Widows and separated women, or women from the lower castes, are often subject to subtle forms of social exclusion, in addition to confronting the effects of frequent floods and droughts, the lowering of water tables, growing scarcity of water and reduction in yields of forest biomass. The negative effects on grain yields of rainfall variability and temperature changes may also increase malnutrition and related health risks (Woodward et al. 1998). While men, not confined to the same extent by domestic and caring responsibilities, have more opportunities than women, and often migrate to earn a living, caste inequalities mediate the outcomes for them too. Poorer and lower-caste men from marginal geographies experience harsh working environments, resulting in ill-health, ultimately increasing the work and care burdens borne by women (Awumbila and Momsen 1995; Rao and Raju 2019).

Caste and class often coincide in South Asia, especially in India and Nepal. Poor households here, especially those in rural areas and dependent on farming or agricultural labour, are likely to be the worst affected, with women in such households facing significant care deficits on account of the increased workload of ensuring household reproduction and care (Ahmed and Fajber 2009; Rao and Raju 2019). Adapting to climate change, then, requires a better understanding not just of the gender divisions of labour, but equally of the mechanisms through which access to and control over natural and other resources are negotiated (Sultana 2014). This in turn implies attention to gender relations, including male contributions to adaptation, whether through migration, other productive activities or support with reproductive work; governance, especially in the provision of basic services and infrastructure; and the enhancement of basic capabilities, including appropriate knowledge, skills and technology.

Within research and policy, the word 'gender' often replaces 'women', not fully taking on board the socially constructed positions that gender relations entail. In a review article asking how far adaptation, vulnerability and resilience research has engaged with gender over the past decade, Bunce and Ford (2015) found that of the 123 articles they reviewed, only one focused on men, and none on other sexual identities. What is still evident in research, but more so in policy, is that women continue to be typically portrayed as overburdened, weak and vulnerable, rather than exercising agency in numerous different ways to cope with adversity and make a living, and more importantly, contributing to meeting their future aspirations for their children (Ghosh et al. 2018; Mitra 2018). Men are invisible, and if at all mentioned, their absence for work is seen as increasing women's burdens and vulnerabilities (Arora-Jonsson 2011; Rao et al. 2017). 


\section{Nitya Rao et al.}

What this brings to the fore is the need to understand the changing power relationships between men and women, but equally the intersecting nature of identities and how they play out in terms of enabling or preventing access to resources and services (Rao et al. 2020). Thus, rather than focusing on women as a unified social category, the impacts of climate change need to be differentiated to better understand how women within socially excluded and economically insecure groups, such as the landless, small-holders, indigenous people or lower-caste groups, may be more intensely affected than other more privileged women (Rao and Raju 2019). In the absence of a differentiated analysis, policy interventions will be unable to strengthen the adaptive capacities of those most in need. Research and policy therefore need to go beyond the collection of sex-disaggregated data to develop an understanding of the multiple, intersecting disadvantages confronting women and men of different social categories and the opportunities available to them for exercising agency in adapting to change (cf. Fraser 1989).

The South Asian region includes seven countries, four of which - Bangladesh, India, Nepal and Pakistan - are included in this volume, primarily because these were the countries where CARIAA research was conducted. While we do not have specific chapters from Sri Lanka, Maldives or Bhutan, we have tried to integrate key insights from these countries in this introductory chapter. Maldives, in particular, as a Small Island Developing State (SIDS), is extremely vulnerable to climate change, especially slow-onset hazards, such as coastal erosion, sea-level rise, salinity intrusion, and change in monsoon patterns and hence rainfall (Government of Maldives 2009). A study in the capital city of Male revealed that more than 50 per cent of respondents viewed sea-level rise as a real threat affecting the country (Stojanov et al. 2017). One of the few studies on the gendered impacts of climate change in the Maldives focuses on changes in the tuna-fishing industry. Similar to other forms of fishing, a gender division of labour exists, with women involved in post-harvest and value-addition activities (Asian Development Bank 2014). Climate change and associated disasters have impacted the production and processing of tuna (Fulu 2007). Despite the guarantee of gender equality in the constitution of the Maldives, women tend to lose out both economically and socially (El-Horr and Pande 2016).

Sri Lanka, also an island state, has some similarities to the Maldives, for instance, its proneness to disasters such as the 2004 tsunami. Based on post-tsunami interviews with 40 widows and widowers, Hyndman (2008) demonstrates that while men could consider remarrying, this was a harder option for women. Yet, this has meant a loss of social support and security. Ethnic conflict, especially in the Northern Province, already poverty-stricken and home to displaced people, and dependent primarily on agricultural livelihoods, has intensified some of these effects (Mani et al. 2018). Fishing is another industry which has been adversely affected; women have lost incomes and been forced to look for other options, often more burdensome and less rewarding. Girls' education has 
suffered in this process (APWLD 2011). Only very recently have some women received support to sustain their livelihoods through the Adaptation Fund (Withanachchi 2019).

Migration is a major issue in Sri Lanka, as in other South Asian countries discussed in this book. Among other aspects of gender discrimination, for instance, the Government of Sri Lanka's Family Background Report (FBR) of 2013 includes policy requiring prospective women migrant domestic workers to document their reproductive and family histories when applying to work overseas. In 2015, the FBR was revised to include women domestic workers in Sri Lanka's tea and rubber estates. The inclusion of the plantation clause raised questions about the state's intention to regulate women's reproductive capacity, alongside restricting the mobility of women wishing to work within and outside the country (Gunathilaka et al. 2018). Similar restrictions were imposed on the migration of young women in Bangladesh (Siddiqui 2003).

Bhutan, a landlocked country in the Himalayan mountains, is increasingly vulnerable to climate change, as witnessed in erratic and extreme rainfall events and glacial lake outburst floods (GLOFs) (ICIMOD 2016). Rising temperatures and uncertain precipitation have made rural settlements prone to landslides, floods and water shortages. With men increasingly moving out in search of work, without credit or alternate sources of employment, women are experiencing growing hardship in their daily lives. They are confined to the informal sector, working hard for low wages, often engaging in risky enterprises carrying a threat of HIV/AIDS, as in other South Asian contexts (ICIMOD 2016). These examples confirm that patriarchy, or the institutionalization of male dominance, manifests itself in different ways across the subcontinent, and to understand these complexities, one needs to consider both social and class positions that mediate the normative boundaries of gender relations across these societies (Hyndman 2008).

In this volume, we focus on a few selected themes that demonstrate diverse strategies and mechanisms for coping and adaptation to climate variability and change. These include male migration, the formation of women's collectives, shifts to drought- and flood-resilient cash crops, and changing gender roles, among others. Contexts of vulnerability and pressures for survival, while intensifying hardship, potentially create spaces for the creative use of agency, and facilitate the loosening of rigid social norms, in the process contributing also to changes in gender and wider social relations. We find, then, an ongoing process of negotiation and renegotiation of roles and responsibilities, but equally decision-making and voice within the household. In its interface with some form of collective action for overcoming technology and scale constraints, social norms in the domains of both production and reproduction are challenged. How far these processes will contribute to attaining both gender justice and climate justice, however, remains to be seen. 


\section{Contributions to the volume}

At the 15th Conference of the Indian Association of Women's Studies in 2017 held in Chennai, for the first time the theme of gender and climate change in India was introduced and the papers presented were later published in the Women's Studies section of the Economic and Political Weekly (EPW) (2018). ${ }^{1}$ Together with two of the papers published in EPW, this book goes beyond the Indian situation to open up the debate on the realities of climate change and its gendered impacts across the subcontinent. The wider focus on the South Asian countries of India, Pakistan, Bangladesh and Nepal has brought in nuances of gender relations across borders, presenting the many similarities and differences across locational, sociocultural and policy contexts. The chapters explore the links between climate variability and environmental change, along with other political economy factors, the precariousness of livelihoods and women's work burdens both in production and reproduction, and their health and nutritional wellbeing and indeed very survival, links that have hardly been explored in the case of South Asia.

Having set out the conceptual framings and assumptions underpinning the study of gender and climate change in South Asia in this introductory chapter, the book goes on to use empirical cases from South Asia to explore the effects of increasing climate variability on poor women and men - their social roles, agency and indeed adaptive capacities. In particular, it focuses on the notions of contextual and relational vulnerabilities (Taylor 2013; Turner 2016), examining how issues such as water scarcity or drought are addressed across contexts, pointing in the process to the gendered nature of water access (Yadav and Lal 2018) and the changing gender roles therein (Kulkarni 2018). We also explore a range of adaptive options available to differently positioned women (Bhatta and Aggarwal 2016; Rao et al. 2019). By adaptive options, we mean "the array of strategies and measures that are available and appropriate for addressing adaptation. They include a wide range of actions that can be categorized as structural, institutional, ecological or behavioural" (IPCC 2018: 542). While male migration emerges as an important adaptation strategy (Bhatta et al. 2016; Jha et al. 2018; Ahsan 2019), the chapters examine the implications of a range of activities that differently positioned women undertake including changing cropping patterns, livestock rearing and petty business to reduce their everyday vulnerabilities. Experiences of women and men in response to alterations in the social-ecological system, be they real or perceived climate stressors, have implications for inter- and intra-household relations and in turn on the wellbeing of individuals (Sarkar 2017; Goodrich et al. 2019).

\section{Unpacking vulnerabilities: intersections of geography and social identity}

While the concept of vulnerability is not a new one, emerging from early literature on famines and the failure of entitlements (Sen 1981) which recognized the political, economic and social embeddedness of people's 
experiences and responses to crises, there is relatively less evidence on the gendered nature of vulnerabilities, especially in response to climatic shifts. With growing acknowledgement of its importance for adaptation planning, a small body of work has been emerging, largely from sub-Saharan Africa. In the case of South Asia, the lack of disaggregated and nuanced information makes writing on this theme a challenge.

Further, much of the literature on climate change in South Asia continues to be framed in complex scientific and technical language, making it difficult to evoke a more fluid sense of climate change as a process affecting the lived experiences of people, women and men, in different parts of the region (cf. O'Brien et al. 2007). It is thus through an intellectually collaborative process that we have tried to use critical gender analytical tools to enable a more nuanced understanding of the implications of climate change for gender relations and household wellbeing. An attempt is made to unpack the gendered nature of risks and vulnerabilities confronting people's lives and livelihoods, the relations of power and social complexities in terms of intersections of gender, caste and class that shape their choices, and the tradeoffs between individual interests and reciprocal exchanges, in adapting to changing circumstances (Rao 2017; Rao et al. 2019). Intersectionality, then, is at the core of conducting a gender analysis of the impacts of climate change (see Qaisrani and Batool in this volume).

Based on the different vulnerabilities and experiences of women across our study locations, we draw attention to the complexities of analyzing climate change. In South Asia, changing climate, whether shrinking glaciers and reduced snow coverage, cyclones, flooding and land erosion, or increasing aridity due to declining rainfall, is an additional stressor, intensifying the burdens of existing poverty. In this volume, Abbasi et al. analyse the role of culture and geography in shaping gendered vulnerabilities and coping with climate change in Pakistan. Climate change in the mountain ecosystems of Nepal and India have affected the water regimes in these areas, in turn altering gender roles and responsibilities, the ownership, rights and control over resources, as well as the very constructions of masculinity and femininity in these contexts (see Tamang and Udas in this volume).

Solomon and Rao, while exploring the implications of depleting ground water levels in rural Tamil Nadu for household livelihoods, emphasize the ways in which the masculine connotations of borewell technology, and the state and community discouragement of women entering these spaces, differentially impact women in this location. The authors observe a simultaneous reversal of the gendered binary in relation to borewells at the household level as women's assets, such as gold, are being called upon for deepening wells or digging new ones, making them partners in these assets. Yet, the loss of control over their gold and its investment in borewells is impacting women's marriage choices, decision-making and overall wellbeing. Udas, Prakash and Goodrich in their chapter from the flood- and drought-prone West Champaran district of Bihar, India, also find women's gold and dowries being increasingly used in response to climate stress and extreme poverty, but given 


\section{Nitya Rao et al.}

the unequal power relations in this location, the women are unable to secure adequate social returns for this contribution. With dowry carrying connotations of son preference, households with more daughters or only daughters have become the most vulnerable in the locality. Both these chapters demonstrate the importance of social location and gendered ideologies in relation to asset control in shaping women's capacities to respond to stressors.

Apart from institutions of the state and society, the effects of climate are also interlinked across scales. Chandni Singh explores the implications of changing patterns of water availability, access and use in a water-scarce district of Karnataka, India, focusing particularly on gendered vulnerability at different scales: the household and intra-household level; settlement and community level; and larger, socio-ecological scale. She notes a shift from a culture of water harvesting and storage to one of unmitigated water extraction, leading to shortages of drinking water. With uneven purchasing power, not all households, especially women-headed households, are able to buy water due both to the high costs involved and lack of time or transport to travel to towns for this purpose. Families unable to buy water then consume unpotable water with severe health implications, and this is the case for a majority of households headed by divorced or widowed women in the study area.

\section{Adaptive strategies: agricultural diversification, migration and collective action}

In the substantially altered world of climate change, women and men both face unprecedented changes, with no standard practices to follow. Livelihood shifts brought about by climate variability, whether in terms of the choice of crops or diversification into non-farm employment, often involve migration from the home. With reduced labour availability, households including those headed by women, in the absence of their men, often turn to cash crops such as sugarcane or vegetables, which are resistant to climate stressors, but also less labour intensive (Udas et al., this volume). This however can result in over-extraction of soil nutrients and water, and while bringing in incomes, could negatively affect the quality of diets, nutrition and health. In this volume, we understand adaptation as the "the process of adjustment to actual or expected climate and its effects, in order to moderate harm or exploit beneficial opportunities" (IPCC 2019:542). From a gender perspective, this would entail integrating the needs of poor and marginalized women, but equally ensuring that they are not further marginalized during the adaptation process (Wigand et al. 2017; Kaufmann 2019; Rao et al. 2019).

\section{Migration as adaptation}

Migration from the hotspots is often viewed as a distress response, with people leaving home as their geographical remoteness limits their access to new livelihood opportunities. Migration can, however, have contradictory effects on both livelihoods and gender relations. In some situations, climate 
change-linked migration can lead to improving economic situations (Hazra et al. and Vincent et al., this volume). At the same time, there are parallel trajectories of exploitation and autonomy accompanying male migration. While women are left in charge of the home and everyday decision-making, their limited mobility and constrained access to public places and institutions accentuates their vulnerability and limits their adaptive capacities. Yet there is a difference between left-behind wives receiving remittances from their husbands, even occasionally, and female-headed households with no male support. Based on their study in Bangladesh, Vincent et al. conclude that fewer women in non-migrant households considered themselves happy compared to those living in migrant households. This is driven partly by women's marital status, but also by the nature of migration itself, whether planned and supported, or forced.

The complexity of migration is visible in Nepal (Tamang et al., this volume), where men more than women have taken advantage of new market opportunities. Carrying the burden of agricultural work, women labour on average nearly 3.5 hours more than men every day. While much of this work involves drudgery, it interestingly also challenges traditional gender divisions of labour, with women taking over work designated as male, such as ploughing and hoeing (Rao et al. 2020). This added responsibility includes new roles for women such as hiring labour, selling livestock and engaging with off-farm activities, usually male prerogatives. Despite higher work and care burdens in often adverse working conditions, it appears that women's fiscal agency is strengthened by changes in power relations within households with increased assets resulting from male migration (see Hazra et al., this volume).

Migration of women as an adaptation strategy is a new area of research and policy advocacy. The paper by Abbasi et al. (this volume) sets the scene for a better understanding of the processes involved, pointing also to the differences that exist within groups of women, as seen in the case of women in up-stream, mid-stream and down-stream areas of the river Indus in Pakistan. The subtle differences across agro-ecologies and social groups highlight the contextual nature of gender relations and roles, and the need for disaggregated perspectives in order to respond effectively to local needs and priorities. Yet as mentioned earlier, legal and policy frameworks, as in the cases of Sri Lanka and Bangladesh, can either support or impede the opportunities available to different categories of women within these countries. The adaptation consequences of migration, then, depend not just on the nature of migration itself, but also on the gendered nature of social institutions that either facilitate or block equitable opportunities for women and men across contexts.

\section{Collective action and resilience}

Climate change and the resulting livelihood diversification, including male outmigration, has opened new spaces for women's agency, individual and collective. While some scholars focus on the expansion of women's roles 
within households (Hazra et al. and Singh in this volume), further research is required to explore the expansion of agency this may entail. Collective action has been the subject of a little more research, as in the Indian Bengal Delta, where women have established spaces for mutual support through self-help groups (Ghosh et al. 2018). In some instances, these groups have facilitated opportunities for women to seek social and economic stability, and avoid risky ventures including sex work. Such organizational space itself opens up a multitude of opportunities and networks, going beyond specific activities linked to microcredit (Kalpana 2017). In West Champaran, in addition to sugarcane cultivation, women left behind have turned to shared animal care as an adaptation strategy as in their perception it is less hazardous than agriculture, while also ensuring mutual support (Udas, Prakash and Goodrich this volume).

Women's significant roles as agents of change in promoting climate-change mitigation action needs to be recognized and supported both individually and collectively (see Qaisrani and Batool, this volume). Rural women's entrepreneurial potential provides one of the entry points enabling women to become change leaders, but this involves overcoming strong cultural constraints to women's mobility and public participation, especially in rural settings. These papers all highlight the link between the two and the importance of collective action for overcoming extreme forms of vulnerability, including challenging entrenched forms of power and inequality.

\section{Conclusion}

Environmental and climatic change is a reality affecting the poor and resourceless the worst. Without a proper understanding of the complexity of issues involved, the links between the geophysical, the agro-ecological and the socio-economic, we will be unable to suggest gender-sensitive policies and support mechanisms. While the risks and vulnerabilities resulting from climate change which intensify gender inequalities have been emphasized in the case of South Asia, our fine-grained analysis points to the enhancement of women's agency in these locations and suggests strategies for supporting such agency. Ownership of assets remains a major constraint to gender equality and can be overcome by new adaptive strategies especially built on women's collectives. Similarly, in contexts of male migration, women's decision-making powers are supplemented by a loosening of gender roles in work, yet they need to be supported in these tasks by social and technological innovations that can ensure that their effort and drudgery does not increase (Rao et al. 2019).

Gender roles and responsibilities are a social construct and vary across communities and geographies. By combining these variables, we have sought to achieve a deeper understanding of the complexity of climate-change impacts. While our empirical evidence and analysis is located in South Asia, the articles collectively demonstrate that women, especially in marginal, rural households, have common interests not just in transforming the 
external environment affected critically by climate change but also in redefining their lives and homes. With the increasing unpredictability of agriculture due to climate change and past and present investments, both public and private, that have undermined the sustainable use of resources, they seek greater cooperation and reciprocity from their husbands and wider kin networks to ensure a life of security and dignity. Drawing specifically from the concrete realities of women's lives, we can construct a larger theoretical argument around women's critical contributions to household livelihoods, more so in an era of climate change. Examining the changing nature of gender relations, roles and responsibilities could help revisit the debates around the "patriarchal bargain" (Kandiyoti 1988).

The chapters in this book seek to deepen and nuance our understanding of gender relations in the context of climate change. They also foreground the need for further research that can identify and highlight innovative adaptation mechanisms on the ground, often led by poor women with little support from state or community institutions. Only by giving recognition to women's agency and their contributions to both paid and unpaid work, to the production and reproduction of their households, can we create an enabling environment which is sensitive to their needs and gives them a voice in decision-making mechanisms. It is not just the issue of vulnerability vs agency, but a better understanding of changing gender relations within households and communities, that will help develop and support sustainable and equitable livelihoods and in turn adaptation.

\section{Note}

1 Review of Women's Studies. 'Gender and Climate Change', Economic and Political Weekly, April 28, 2018. Vol LIII No 17. Pp. 35-37, 38-45, 46-54, 63-69.

\section{References}

Abid, M.E.A., Scheffran, J., Schneider, U.A., and Ashfaq, M. 2015. 'Farmers' perceptions of and adaptation strategies to climate change and their determinants: The case of Punjab province, Pakistan', Earth System Dynamics, 6(1): 225-243. Adger, W.N. 2006. 'Vulnerability', Global Environmental Change, 16(3): 268-281. Ahmed, S., and Fajber, E. 2009. 'Engendering adaptation to climate variability in Gujarat, India', Gender \& Development, 17(1): 33-50.

Ahsan, R. 2019. 'Climate-induced migration: Impacts on social structures and justice in Bangladesh', South Asia Research, 0262728019842968.

Allen, M.R., Dube, O.P., Solecki, W., Aragón-Durand, F., Cramer, W., Humphreys, S., Kainuma, M., Kala, J., Mahowald, N., Mulugetta, Y., Perez, R., Wairiu, M., and Zickfeld, K. 2018. 'Framing and Context' In: Global Warming of $1.5^{\circ} \mathrm{C}$. An IPCC Special Report on the impacts of global warming of $1.5^{\circ} \mathrm{C}$ above pre-industrial levels and related global greenhouse gas emission pathways, in the context of strengthening the global response to the threat of climate change, sustainable development, and efforts to eradicate poverty [Masson-Delmotte, V., P. Zhai, H.-O. Pörtner, D. Roberts, J. Skea, P.R. Shukla, A. Pirani, W. Moufouma-Okia, C. 


\section{Nitya Rao et al.}

Péan, R. Pidcock, S. Connors, J.B.R. Matthews, Y. Chen, X. Zhou, M.I. Gomis, E. Lonnoy, T. Maycock, M. Tignor, and T. Waterfield (eds)]. In press

Amarnath, G., Alahacoon, N., Smakhtin, V., and Aggarwal, P. 2017. Mapping multiple climate-related hazards in South Asia (Vol. 170). International Water Management Institute (IWMI).

APWLD. 2011. Climate justice briefs: Rural women's adaptation strategies. Asia Pacific Forum on Women, Law and Development. Sri Lanka.

Arora-Jonsson, S. 2011. 'Virtue and vulnerability: Discourses on women, gender and climate change', Global Environmental Change, 21: 744-751.

Asian Development Bank. 2014. Maldives: Gender equality diagnostic of selected sectors. Mandaluyong City: Asian Development Bank.

Awumbila, M., and Momsen, J.H. 1995. 'Gender and the environment: Women's time use as a measure of environmental change', Global Environmental Change, 5(4): 337-346.

Bhatta, G.D., and Aggarwal, P.K. 2016. 'Coping with weather adversity and adaptation to climatic variability: a cross-country study of smallholder farmers in South Asia', Climate and Development, 8(2): 145-157.

Bhatta, G.D., Aggarwal, P.K., Poudel, S., and Belgrave, D.A. 2016. 'Climate-induced migration in South Asia: Migration decisions and the gender dimensions of adverse climatic events', Journal of Rural and Community Development, 10(4).

Bunce, A., and Ford, J. 2015. How is adaptation, resilience and vulnerability research engaging with gender? Environmental Research Letters, 10: 123003. http://iopscience.iop.org/article/10.1088/1748-9326/10/12/123003

Cannon, T. 2002. 'Gender and climate hazards in Bangladesh', Gender \&o Development, 10(2): 45-50.

Dankelman, I., Alam, K., Ahmed, W.B., Gueye, Y.D., Fatema, N., and Mensah-Kutin, R. 2008. Gender, climate change and human security: Lessons from Bangladesh, Ghana and Senegal. New York: WEDO, ABANTU for Development, ActionAid and ENDA.

Dankelman, I. 2010. Gender and climate change: An introduction. London: Earthscan.

De Souza, K., Kituyi, E., Harvey, B., Leone, M., Murali, K.S., and Ford, J.D. 2015. 'Vulnerability to climate change in three hot spots in Africa and Asia: KEY issues for policy-relevant adaptation and resilience-building research', Regional Environmental Change, 15: 747. doi:10.1007/s10113-015-0755-8

Demetriades, J., and Esplen, E. 2008. 'The gender dimensions of poverty and climate change adaptation', Ids Bulletin, 39(4): 24-31.

Denton, F. 2002. 'Climate change vulnerability, impacts, and adaptation: Why does gender matter?', Gender \&o Development, 10(2): 10-20.

Dixon-Mueller, R.B. 2013. Rural women at work: Strategies for development in South Asia. New York: RFF Press.

Djoudi, H., Locatelli, B., Vaast, C., Asher, K., Brockhaus, M. and Sijapati, B.B. 2016. 'Beyond dichotomies: Gender and intersecting inequalities in climate change studies', Ambio, 45(3): 248-262.

El-Horr, J., and Pande, R.P. 2016. Understanding gender in Maldives: Towards inclusive development (English). Direction in development. Country and regions. Washington, DC: World Bank Group. http://documents.worldbank.org/curated/ en/448231467991952542/Understanding-gender-in-Maldives-towards-inclusivedevelopment 
Faisal, I.M., and Parveen, S. 2004. 'Food security in the face of climate change, population growth, and resource constraints: Implications for Bangladesh', Environmental Management, 34(4): 487-498.

Farooqi, A.B., Khan, A.H., and Mir, H. 2005. 'Climate change perspective in Pakistan', Pakistan Journal of Meteorology, 2(3).

Ford, J.D., Berrang-Ford, L., Bunce, A., McKay, C., Irwin, M., and Pearce, T. 2015. 'The status of climate change adaptation in Africa and Asia', Regional Environmental Change, 15(5): 801-814.

Fraser, N. 1989. Unruly practices: Power, discourse and gender in contemporary social theory. University of Minnesota Press.

Fulu, E. 2007. 'Gender, vulnerability, and the experts: Responding to the Maldives tsunami', Development and Change, 38(5): 843-864.

Gentle, P., and Maraseni, T.N. 2012. 'Climate change, poverty and livelihoods: Adaptation practices by rural mountain communities in Nepal', Environmental Science \& Policy, 21: 24-34.

Ghosh, A.K., Banerjee, S., and Naaz, F. 2018. 'Adapting to Climate Change - induced Migration', Review of Women's Studies, Economic and Political Weekly 53 (17): 63-69.

Goodrich, C.G., Udas, P.B., and Larrington-Spencer, H. 2019. 'Conceptualizing gendered vulnerability to climate change in the Hindu Kush Himalaya: Contextual conditions and drivers of change', Environmental Development, 31: 9-18. https:// doi.org/10.1016/j.envdev.2018.11.003

Government of Maldives. 2009. National Adaptation to Climate Change. A background paper prepared by the Ministry of Housing, Transport and Environment for the Maldives Partnership Forum (MPF) to be held in Maldives, 23-24 March 2009:1

Gunaratna, K.L. 2018. 'Managing climate change in South Asia.' In Towards equitable progress (pp. 53-69). Singapore: Springer.

Gunathilaka, R.P.D., Smart, J.C.R., Fleming, C.M., and Hasan, S. 2018. 'The impact of climate change on labour demand in the plantation sector: The case of tea production in Sri Lanka', Australian Journal of Agricultural and Resource Economics, 62(3): 480-500. doi:10.1111/1467-8489.12262

Hyndman, J. 2008. 'Feminism, conflict and disasters in post-tsunami Sri Lanka', Gender, Technology and Development, 12(1):101-121.

ICIMOD. 2016. Bhutan Climate + Change Handbook by Bhutan Media and Communications Institute Bhutan and International Centre for Integrated Mountain Development Kathmandu. http:/lib.icimod.org/record/32399/files/ icimodBhutanClimate016.pdf

IPCC. 2018. 'Annex I: Glossary' [Matthews, J.B.R. (ed.)]. In: Global Warming of $1.5^{\circ} \mathrm{C}$. An IPCC Special Report on the impacts of global warming of $1.5^{\circ} \mathrm{C}$ above pre-industrial levels and related global greenhouse gas emission pathways, in the context of strengthening the global response to the threat of climate change, sustainable development, and efforts to eradicate poverty [Masson-Delmotte, V., P. Zhai, H.-O. Pörtner, D. Roberts, J. Skea, P.R. Shukla, A. Pirani, W. MoufoumaOkia, C. Péan, R. Pidcock, S. Connors, J.B.R. Matthews, Y. Chen, X. Zhou, M.I. Gomis, E. Lonnoy, T. Maycock, M. Tignor, and T. Waterfield (eds)]. In Press.

IPCC. 2019. 'Summary for Policymakers.' In IPCC Special Report on the ocean and cryosphere in a changing climate [H.-O. Pörtner, D.C. Roberts, V. Masson-Delmotte, 


\section{Nitya Rao et al.}

P. Zhai, M. Tignor, E. Poloczanska, K. Mintenbeck, A. Alegría, M. Nicolai,

A. Okem, J. Petzold, B. Rama, N.M. Weyer (eds)]. In press.

Jha, C.K., Gupta, V., Chattopadhyay, U., and Amarayil Sreeraman, B. 2018. 'Migration as adaptation strategy to cope with climate change: A study of farmers' migration in rural India', International Journal of Climate Change Strategies and Management, 10(1): 121-141.

Kalpana, K. 2017. Women, microfinance and the state in neo-liberal India. New Delhi: Routledge.

Kandiyoti, D. 1988. 'Bargaining with patriarchy', Gender and Society, 2 (3): 274-290.

Kaufmann, W. 2019. 'Vulnerabilities in a Wetter World: A study on migration as an adaptation strategy to climate change, with under-five mortality as an intermediating variable.' Department of Economics, Uppsala University, Sweden. Accessed on 12 Nov 2020 from http://urn.kb.se/resolve?urn=urn:nbn:se:uu:diva-376870.

Kulkarni, S. 2018. 'Gender, water and well-being.' In Narain, V., Goodrich, C.G., Chourey, J., and A. Prakash (eds). Globalization of water governance in South Asia, pp. 19-34. New Delhi: Taylor \& Francis, Routledge.

MacGregor, S. 2010. 'Gender and climate change: From impacts to discourses', Journal of the Indian Ocean Region, 6(2): 223-238. doi:10.1080/19480881. 2010.536669.

Mani, M., Bandyopadhyay, S., Chonabayashi, S., Markandya, A., and Mosier, T. 2018. South Asia's hotspots: The impact of temperature and precipitation changes on living standards. Washington, DC: World Bank. 10.1596/978-1-4648-1155-5.

Mitra, A. 2018. 'Male migrants and women farmers in Gorakhpur', Economic and Political Weekly, 53(17): 55-62.

O'Brien, K., Eriksen, S., Nygaard, L.P., and Schjolden, A. 2007. 'Why different interpretations of vulnerability matter in climate change discourses', Climate Policy, 7: 73-88.

Otto, I.M., Reckien, D., Reyer, C.P., Marcus, R., Le Masson, V., Jones, L., Norton, A. and Serdeczny, O. 2017. Social vulnerability to climate change: A review of concepts and evidence. Regional Environmental Change, 17(6):1651-1662.

Pant, G.B., Kumar, P.P., Revadekar, J.V., and Singh, N. 2018. 'Climate and climate change: An overview.' In Climate change in the Himalayas, pp. 1-38. Cham: Springer.

Pearse, R. 2017. 'Gender and climate change', Wiley Interdisciplinary Reviews: Climate Change, 8(2): e451.

Rajasree, R. 2010. 'Gender and climate change', Commodity Vision, 3(5): 99-101.

Ramanathan, V., Chung, C., Kim, D., Bettge, T., Buja, L., Kiehl, J.T., Washington, W.M., Fu, Q., Sikka, D.R., and Wild, M. 2005. 'Atmospheric brown clouds: Impacts on South Asian climate and hydrological cycle', Proceedings of the National Academy of Sciences, 102(15): 5326-5333.

Rao, A. and Kelleher, D., 2005. Is there life after gender mainstreaming? Gender \& Development, 13(2), 57-69.

Rao, N., and Raju, S. 2019. 'Gendered time, seasonality, and nutrition: Insights from two Indian Districts', Feminist Economics, 26(2): 95-125.

Rao, N. 2017. 'Assets, agency and legitimacy: Towards a relational understanding of gender equality policy and practice', World Development, 95(3): 45-54. doi:10.1016/j.worlddev.2017.02.018.

Rao, N, Lawson, E. T., Raditloaneng, N, Solomon, D and Angula, M. 2017. 'Gendered Vulnerabilities to Climate Change: Insights from the Semi-Arid 
Regions of Africa and Asia, Climate and Development 11(1): 14-26. doi: 10.1080/17565529.2017.1372266.

Rao, N., Mishra, A., Prakash, A., Singh, C., Qaisrani, A., Poonacha, P., Vincent, K. and Bedelian, C. 2019. 'A qualitative comparative analysis of women's agency and adaptive capacity in climate change hotspots in Asia and Africa', Nature Climate Change, 9: 964-971.

Rao, N., Singh, C., Solomon, D., Camfield, L., Sidiki, R., Angula, M., Poonacha, P., Sidibe, A., and Lawson, E.T. 2020. 'Managing risk, changing aspirations and household dynamics: Implications for wellbeing and adaptation in semi-arid Africa and India', World Development, 125.

Rasul, G., Mahmood, A., Sadiq, A., and Khan, S.I. 2012. 'Vulnerability of the Indus delta to climate change in Pakistan', Pakistan Journal of Meteorology, $8(16)$.

Sarkar, R. 2017. Women and water: Adaptation practices to climate variability in the Sikkim Himalaya (Doctoral dissertation).

Sen, A. 1981. 'Ingredients of famine analysis: Availability and entitlements', The Quarterly Journal of Economics, 96(3): 433-464.

Siddiqui, T. 2003. 'An Anatomy of Forced and Voluntary Migration from Bangladesh: A Gendered Perspective.' In: Morokvasic M., Erel U., Shinozaki K. (eds) Crossing Borders and Shifting Boundaries. Schriftenreihe der Internationalen Frauenuniversität »Technik und Kultur«, 10: 155-176. Wiesbaden: VS Verlag für Sozialwissenschaften.

Sivakumar, M.V., and Stefanski, R. 2010. 'Climate change in South Asia.' In Climate change and food security in South Asia. Dordrecht: Springer.

Stojanov, R., Duží, B., Kelman, I., Němec, D., and Procházka, D. 2017. 'Local perceptions of climate change impacts and migration patterns in Malé, Maldives', The Geographical Journal, 183(4): 370-385.

Sultana, F. 2014. 'Gendering climate change: Geographical insights', The Professional Geographer, 66(3): 372-381.

Taylor, M. 2013. 'Climate change, relational vulnerability and human security: Rethinking sustainable adaptation in agrarian environments', Climate and Development, 5(4): 318-327.

Turner, M.D. 2016. 'Climate vulnerability as a relational concept', Geoforum, 68: 29-38.

Vinke, K., Martin, M.A., Adams, S., Baarsch, F., Bondeau, A., Coumou, D., and Robinson, A. 2017. 'Climatic risks and impacts in South Asia: Extremes of water scarcity and excess', Regional Environmental Change, 17(6): 1569-1583.

Wigand, C., Ardito, T., Chaffee, C., Ferguson, W., Paton, S., Raposa, K., Vandemoer, C. and Watson, E. 2017. 'A climate change adaptation strategy for management of coastal marsh systems', Estuaries and Coasts, 40(3): 682-693.

Withanachchi,A.2019.'Despite all odds: climate resilient women in Sri Lanka.' https:// www.adaptation-undp.org/despite-all-odds-climate-resilient-women-sri-lanka

Woodward, A., Hales, S., and Weinstein, P. 1998. 'Climate change and human health in the Asia Pacific region: Who will be most vulnerable?', Climate Research, 11(1): 31-38.

Yadav, S.S., and Lal, R. 2018. 'Vulnerability of women to climate change in arid and semi-arid regions: The case of India and South Asia', Journal of Arid Environments, 149, 4-17. 


\section{Nitya Rao et al.}

Young, Z.P. 2016. 'Gender and development.' In Handbook on gender in world politics. Cheltenham: Edward Elgar Publishing.

Yu, W., Alam, M., Hassan, A., Khan, A.S., Ruane, A., Rosenzweig, C., Major, D. and Thurlow, J. 2010. Climate change risks and food security in Bangladesh. London: Routledge. 